\title{
Artikel
}

\section{Amerikanisering van corruptiebestrijding}

\author{
Buitengerechtelijke afdoening en andere tendensen in de handhaving van \\ anticorruptiewetgeving
}

F. Haijer, LL.M. en mr. dr. E. Sikkema*

\section{Inleiding}

In de jaren 2014-2017 heeft in Nederland een grote omschakeling plaatsgevonden op het terrein van de handhaving in buitenlandse corruptiezaken. Hoewel het omkopen van een buitenlandse ambtenaar al langer strafbaar was (zie art. 178a lid $1 \mathrm{Sr}),{ }^{1}$ werd Nederland tot 2014 geclassificeerd als een 'niet-handhaver' door Transparency International en de Organisatie voor Economische Samenwerking en Ontwikkeling (OECD). ${ }^{2} \mathrm{Er}$ had tot die tijd nog nooit een veroordeling of transactie voor buitenlandse corruptie plaatsgevonden. In 2014 kwam daar verandering in, toen het $\mathrm{OM}$ een transactie van 240 miljoen euro afsloot met SBM Offshore voor omkoping in Brazilië, Angola en Equatoriaal Guinea. Dit bedrag bestond voor 40 miljoen euro uit een 'boete' en voor 200 miljoen euro uit een ontneming van het wederrechtelijk verkregen voordeel. ${ }^{3}$ In 2016 volgde Vimpelcom, met een transactie van bijna 400 miljoen

* F. Haijer, LL.M is promovenda aan de Universiteit Utrecht en interimdirecteur Transparency International Nederland. Mr. dr. E. Sikkema is universitair docent straf(proces)recht aan de Universiteit Utrecht. Onderzoek dat resulteerde in deze publicatie werd gefinancierd door de European Research Council (proposal 336230 UNIJURIS).

1. Wet van 13 december 2000, Stb. 616 , in werking getreden op 1 februari 2001.

2. https://www.transparency.org/whatwedo/publication/exporting corruption_progress_report_2014_assessing_enforcement_of_the_oecd en http://www.oecd.org/daf/anti-bribery/Working-Group-on-BriberyEnforcement-Data-2013.pdf.

3. https://www.om.nl/vaste-onderdelen/zoeken/@87202/sbm-offshorebetaalt/. euro voor omkoping in Oezbekistan. Dit bedrag bestond voor 100 miljoen euro uit een 'boete'. Tegelijkertijd werd door Vimpelcom met de Amerikaanse autoriteiten een schikking voor precies hetzelfde bedrag getroffen. ${ }^{4}$ Takilant, een brievenbusfirma die was opgericht met als doel deze omkoping te faciliteren, werd bij verstek veroordeeld tot een boete van 1,6 miljoen euro en een ontneming van wederrechtelijk verkregen voordeel van 123 miljoen euro. ${ }^{5}$ Een transactie met TeliaSonera, bij dezelfde omkoping betrokken als Vimpelcom en Takilant, volgde in $2017 .{ }^{6}$ Dit betrof wederom een schikking van honderden miljoenen en er was weer nauwe samenwerking met de Verenigde Staten van Amerika (VS).

Het lijkt erop dat het Nederlandse handhavingsbeleid op het terrein van buitenlandse corruptie steeds meer 'amerikaniseert', en daarmee ansluit bij een algemene trend die volgens Van Swaaningen al meer dan dertig jaar zichtbaar is in het Nederlandse strafrecht. ${ }^{7}$ In deze bijdrage verklaren wij deze ontwikkeling op het terrein van antibuitenlandse corruptie allereerst vanuit het perspectief van Amerikaans buitenlands beleid, dat onder meer tot doel heeft te zorgen dat buitenlandse staten meer gaan handhaven. Vervolgens beschouwen wij de stand van zaken met betrekking tot buitengerechtelijke afdoening in Nederland, in het bijzonder de hoge of bijzondere transactie en de strafbeschikking. We gaan hier-

4. https://www.om.nl/vaste-onderdelen/zoeken/@93225/vimpelcombetaalt/.

5. Rb. Amsterdam 20 juli 2016, ECLI:NL:RBAMS:2016:4520 en ECLI:NL:RBAMS:2016:4594.

6. https://www.om.nl/actueel/nieuwsberichten/@100343/internationale $-0 \%$.

7. R. van Swaaningen, 'Waarom kijken wij eigenlijk naar Amerika?', Justitiële Verkenningen 2013, nr. 8, p. 37-51. 
bij in op de handhavingspraktijk, maatschappelijke en wetenschappelijke kritiek en werpen gezien de voorgenomen modernisering van het Wetboek van Strafvordering ook een blik op de toekomst. In het bijzonder staan wij stil bij de mogelijke introductie van een rechterlijke toets van hoge en bijzondere transacties. Wij sluiten af met een onderwerp dat weliswaar iets verder over de horizon ligt, maar waar wij gezien de eerder geschetste ontwikkelingen groeiende aandacht voor verwachten: het compenseren van slachtoffers van buitenlandse corruptie.

\section{Ontwikkelingen in de VS en samenwerking met Nederland}

Het Nederlandse handhavingsbeleid ten aanzien van buitenlandse omkoping kan onzes inziens inderdaad niet los gezien worden van ontwikkelingen in de VS. De VS is wereldwijd sinds jaar en dag de meest agressieve handhaver van strafbaarstellingen van het omkopen van buitenlandse ambtenaren. Sinds de OECD Working Group on Bribery in 2009 begon met het publiceren van handhavingscijfers, steekt de VS ieder jaar met kop en schouders boven de rest van de OECD-leden uit. ${ }^{8}$ De harde Amerikaanse handhaving - met hoge sancties leidde tot veel kritiek van het Amerikaanse bedrijfsleven: de Amerikaanse wetgeving, de Foreign Corrupt Practices Act (FCPA) zou leiden tot een oneerlijke concurrentiepositie voor buitenlandse bedrijven ten opzichte van Amerikaanse bedrijven. Het gezag van de Amerikaanse instituten die verantwoordelijk zijn voor het handhaven van de FCPA, de Department of Fustice (DoJ) en Securities and Exchange Commission (SEC) lag onder vuur. Doordat er veelal sprake was van buitengerechtelijke afdoening zonder rechtelijke toets (zie verder paragraaf 4) en aangezien de sancties in de honderden miljoenen liepen, lag het voor de hand dat de DoJ en SEC verweten werd dat ze te veel macht hadden. ${ }^{9}$ Er was ook kritiek dat de FCPA niet meer was dan een 'cash com' voor de gehele juristerij, waaronder bedrijfsadvocaten, compliance-bedrijven en de overheidsinstellingen zelf. Het Institute for Legal Reform, onderdeel van de Amerikaanse Chamber of Commerce, waarin onder meer managers van Walmart, General Electric, ExxonMobil en Dow Chemical in het bestuur zaten, pleitte voor aanpassing van de wet. ${ }^{10}$ Naast het veelvuldig vervolgen van

8. Zie de volgende website voor data van 2009 tot en met 2016: http:// www.oecd.org/daf/anti-bribery/data-on-enforcement-of-the-antibribery-convention.htm.

9. M. Koehler, 'The Facade of FCPA Enforcement', Georgetown Journal of International Law 41, no. 4 (2010), p. 907-1010.

10. https://www.uschamber.com/restoring-balance-proposed-amendments -foreign-corrupt-practices-act en zie ook https://www.washingtonpost. com/business/economy/wal-mart-took-part-in-lobbying-campaign-toamend-anti-bribery-law/2012/04/24/gIQAyZcdfT_story.html?utm_ term $=. e f 3 c 3 d b 73568$. buitenlandse bedrijven, wat al gebeurde, ${ }^{11}$ reageerden de Amerikaanse autoriteiten op twee manieren op deze binnenlandse kritiek: meer investeren in buitenlandse anticorruptie-instellingen en meer samenwerken met buitenlandse autoriteiten. Deze beleidslijnen hebben allebei als uiteindelijk doel dat buitenlandse autoriteiten hun eigen bedrijven meer vervolgen, zodat Amerikaanse bedrijven niet langer ervaren dat ze oneerlijk behandeld worden als zij zakendoen in het buitenland.

De eerstgenoemde Amerikaanse beleidslijn, het versterken van buitenlandse handhavende instanties, wordt uitgevoerd onder verantwoordelijkheid van het Amerikaanse ministerie van Buitenlandse Zaken, het State Department, met als formeel doel het creëren van een gelijk speelveld voor Amerikaanse bedrijven in elke regio van de wereld. ${ }^{12}$ Dit gelijke speelveld wordt dan ook genoemd als doel van ontwikkelingssamenwerking op het gebied van corruptiebestrijding. ${ }^{13}$ Het grootste deel van het anticorruptieontwikkelingsgeld wordt gebruikt voor het oprichten en versterken van anticorruptiecentra wereldwijd. ${ }^{14}$ Dit gebeurde onder meer in Indonesië, de Filippijnen, Servië, Afghanistan, Mongolie, Peru, El Salvador, Bangladesh en Madagaskar. ${ }^{15}$

Vooral het tweede beleidsvoornemen, meer samenwerken met buitenlandse handhavende instanties, heeft effect in Nederland. De uitvoering van dit beleid gebeurt onder meer door het plaatsen van 'lam enforcement attachés' in het buitenland en door het gebruikmaken van informele netwerken, om zo - zaak voor zaak tot meer handhaving te komen. Het Verdrag van de Verenigde Naties (VN) tegen corruptie (UNCAC) wordt door de Amerikaanse autoriteiten gezien als juridische basis voor deze vormen van internationale samenwerking. ${ }^{16}$ Andrew Ceresney, directeur handhaving bij de SEC, bedankte eind 2016 de autoriteiten van in het bijzonder Brazilië en Nederland voor de goede samenwerking in de zaken Vimpelcom en Embraer en sprak de verwachting uit dat er in de toekomst nog veel van zulke samenwerkingen zullen volgen. Ceresney zegde ook toe dat inkomsten uit ontneming en sancties door de VS met buitenlandse autoriteiten zullen worden gedeeld, zoals ook gebeurde met Nederland in de zaak Vimpelcom, om zo de efficiëntie van wereldwijde schikkingsprocessen te verbeteren. ${ }^{17}$

Ook in de zaak SBM Offshore was de Amerikaanse betrokkenheid duidelijk. In de woorden van officier van justitie Rutger Jeuken: 'De resultaten en stappen in de afdoening werden voortdurend afgestemd met de Ame-

11. A.D. Westbrook, 'Enthusiastic Enforcement, Informal Legislation: The Unruly Expansion of the Foreign Corrupt Practices Act', Georgia Law Review vol. 45, no. 2 (Winter 2011), p. 489-578.

12. https://www.state.gov/anticorruption/index.htm

13. https://www.usaid.gov/sites/default/files/documents/1866/ AnalysisUSAIDAnticorruptionProgrammingWorldwideFinalReport20072013.pdf, annex 1.0 on background, p. 3.

14. Ibid, p. 5

15. Ibid. p. 28.

16. CAC/COSP/IRG/I/1/1/Add.6, Review of implementation of the United Nations Convention against Corruption, p. 20.

17. https://www.sec.gov/news/speech/speech-ceresney-113016.html. 
rikaanse autoriteiten. ${ }^{18}$ En ook Marnix Somsen, de advocaat van SBM Offshore, legt duidelijk de link tussen de Amerikaanse handhavingspraktijk en de Nederlandse transactie met SBM Offshore. Hij spreekt in verband met de FCPA-schikkingen met Philips, Rabobank en ING over 'allemaal Nederlandse euro's die in Amerikaanse staatszakken belanden. ${ }^{19}$ Somsen legt uit dat hij er als advocaat voor pleit dat het Nederlandse OM meer gaat handhaven en transigeren, zodat bedrijven een zaak in Nederland af kunnen doen in plaats van in de VS.

De amerikanisering van anticorruptiehandhaving leidt ook tot een hogere waardering voor effectiviteit en efficiëntie in de handhaving. Uit het persbericht over SBM Offshore blijkt dat vanuit overwegingen van efficiëntie de keuze is gemaakt om te focussen op de belangrijkste corruptiegevallen, terwijl er kennelijk nog veel meer aan de hand was. ${ }^{20}$ En van het sinds 1 september 2016 operationele anticorruptiecentrum van de FIOD wordt verwacht dat het zijn eigen budget terugverdient en daarnaast nog 80 miljoen euro per jaar incasseert an transacties, boetes en ontnemingen. ${ }^{21}$ Er lijkt met deze stap geen weg meer terug naar 'niet-handhaving' en wij verwachten dan ook dat er nog meer grote schikkingen zullen volgen.

\section{Buitengerechtelijke afdoening van corruptiezaken}

\subsection{De (hoge of bijzondere) transactie}

Vanouds kent het Nederlandse strafrecht de buitengerechtelijke afdoening in de vorm van de transactie. ${ }^{22} \mathrm{Op}$ grond van artikel $74 \mathrm{Sr}$ kan het Openbaar Ministerie $(\mathrm{OM})$ voor de aanvang van de terechtzitting één of meer voorwaarden stellen ter voorkoming van strafvervolging wegens misdrijven waarop een gevangenisstraf van niet meer dan zes jaren is gesteld en voor overtredingen. Actieve omkoping van een ambtenaar kan op grond van artikel $177 \mathrm{Sr}$ worden gestraft met een gevangenisstraf van ten hoogste zes jaren en kan dus met een transactie worden afgedaan. ${ }^{23}$ Voor deze bijdrage is vooral van belang dat de voorwaarde kan worden gesteld dat een geldsom moet worden betaald aan de staat, waarvan de hoogte is gebonden aan de maximale geldboete die voor het feit kan worden opgelegd. In het geval van actieve ambtelijke omkoping (art. $177 \mathrm{Sr}$ ) is dat een geldboete

18. https://www.om.nl/vaste-onderdelen/zoeken/@89993/sbm-offshoreschikt/.

19. https://www.nrc.nl/nieuws/2014/12/20/ruzie-maken-marnix-somsendoet-het-vaak-maar-wel-voor-zijn-werk-a1498470.

20. https://www.om.nl/vaste-onderdelen/zoeken/@87202/sbm-offshorebetaalt/.

21. Gebaseerd op interviews en observaties in het kader van promotieonderzoek door F. Haijer in de periode 2015/2016.

22. Het voorwaardelijk sepot blijft hier verder buiten beschouwing.

23. Dat geldt overigens niet voor de actieve omkoping van een rechter, die kan worden gestraft met een gevangenisstraf van ten hoogste negen jaren (art. $178 \mathrm{Sr}$ ) van de vijfde categorie, dat wil zeggen 82.000 euro (art. $23 \mathrm{lid} 4 \mathrm{Sr}$ ). Als het gaat om een rechtspersoon kan een geldboete van de naast hogere categorie (de zesde categorie: 820.000 euro) worden opgelegd, dan wel - wanneer die boetecategorie geen passende bestraffing toelaat - een geldboete tot ten hoogste tien procent van de jaaromzet van de rechtspersoon in het voorafgaande boekjaar (art. 23 lid $7 \mathrm{Sr}$ ). Als sprake is van meerdere omkopingsgevallen geldt ten aanzien van geldboetes dat deze onbeperkt kunnen cumuleren (art. 57 lid 2 Sr). Dat kan per saldo dus leiden tot (zeer) hoge boetes. ${ }^{24}$ Een andere relevante voorwaarde in corruptiezaken is de voldoening van een geldbedrag ter ontneming van het wederrechtelijk verkregen voordeel. Door de voldoening aan deze voorwaarden vervalt het recht tot strafvordering (art. 74 lid $1 \mathrm{Sr}$ ). Hoewel vanuit het OM wel wordt betoogd dat het accepteren van een transactievoorstel als een schuldbekentenis wordt beschouwd, ${ }^{25}$ wordt de schuld van de verdachte dus niet (formeel) vastgesteld. ${ }^{26}$

Oorspronkelijk was de transactieregeling bedoeld voor het afdoen van met name lichtere strafzaken om daarmee het gerechtelijke systeem te ontlasten. Gaandeweg is deze echter steeds vaker toegepast in meer complexe (fraude)zaken. ${ }^{27}$ In de 'Aanwijzing hoge en bijzondere transacties' worden regels gegeven voor de te volgen procedure bij het aanbieden van hoge transacties en transacties in bijzondere zaken. ${ }^{28}$ Het uitgangspunt in dit soort gevallen is volgens de Aanwijzing: niet transigeren (maar voorleggen aan de rechter) tenzij daar een zeer goede reden voor is. Als in een concreet geval toch voor een transactie wordt gekozen, zal de officier van justitie moeten motiveren waarom het algemeen belang niet gediend is bij het dagvaarden van de verdachte. ${ }^{29}$ De voorgenomen transactie moet vervolgens via de parketleiding en het College van procureurs-generaal aan de minister van Justitie en Veiligheid worden voorgelegd.

Een transactie geldt in beginsel als 'hoge transactie' in de zin van de Aanwijzing als (a) de voorwaarde de betaling van een geldsom aan de staat betreft (als bedoeld in art. 74 lid 2 sub a Sr) die het bedrag van 50.000 euro te boven gaat of als (b) het totale bedrag dat met de transactie gemoeid is (inclusief eventuele bedragen ter voordeelsontneming of schadevergoeding) het bedrag van

24. Vgl. T. van Roomen \& A. Verbruggen, 'Corruptie: status quo en de toekomst', TBS\&H 2015, p. 233.

25. Volgens hoofdofficier van justitie Marianne Bloos van het Functioneel Parket komt een schikking alleen in beeld als de verdachte ook zelf het foute van zijn handelen inziet en schuld erkent; zie daarover de opinie van advocaat Madelon Stevens in het Financieele Dagblad van 1 maart 2018. Stevens betoogt dat dit een reden kan zijn om het transactievoorstel niet te accepteren en dat de voordelen van een transactie ten opzichte van een procedure voor de rechter steeds verder te zoeken zijn.

26. Zie ook J.I.P. Hofstee, 'Buitenlandse corruptie in Nederland en de VS: een geschikte aanpak?', Tijdschrift voor Bijzonder Strafrecht \& Handhaving 2017, p. 29.

27. Hofstee 2017, p. 29.

28. Stcrt. 2008, 209.

29. K.C.J. Vriend, 'De hoge en bijzondere transactie: een pleidooi voor rechterlijke controle op de afdoening buiten geding', TBS\&H 2016, p. 196. 
500.000 euro te boven gaat. ${ }^{30}$ Van een 'bijzondere transactie' kan volgens de Aanwijzing sprake zijn als de zaak heeft geleid tot grote nationale maatschappelijke bezorgdheid of onrust. Deze categorie betreft onder meer kwesties die twijfel doen rijzen an de integriteit van de Nederlandse overheid. De transacties die in de inleiding werden genoemd (SBM Offshore, Vimpelcom, TeliaSonera) betreffen overigens steeds de omkoping van buitenlandse ambtenaren (in de zin van art. 178a Sr). ${ }^{31}$ Gelet op de enorme bedragen die ermee gemoeid waren, zijn zij uiteraard zonder meer als 'hoge transacties' aan te merken. En gezien de maatschappelijke bezorgdheid over grootschalige corruptie door Nederlandse bedrijven lijkt een kwalificatie als 'bijzondere transactie' eveneens voor de hand te liggen.

Indien besloten wordt tot een hoge of bijzondere transactie is een persbericht in beginsel noodzakelijk. Dit persbericht compenseert volgens de Aanwijzing het uitblijven van publiciteit naar aanleiding van een openbare behandeling ter terechtzitting en de generaal preventieve werking die daarvan uitgaat. Het persbericht vermeldt in elk geval de naam van de verdachte en geeft summier aan waarom gekozen is voor een transactie. ${ }^{32}$

\subsection{De strafbeschikking}

Met de Wet OM-afdoening is de strafbeschikking in 2008 geintroduceerd in onze strafrechtspleging. ${ }^{33}$ Het belangrijkste verschil ten opzichte van de transactie is dat de officier van justitie de bevoegdheid heeft gekregen om zelf strafbare feiten af te doen via een eenzijdig op te leggen strafbeschikking. Het consensuele element van de transactie is in zoverre verdwenen. Bij de transactie is daarentegen instemming vereist met het transactieaanbod. De transactie wordt dan ook algemeen gezien als een publiekrechtelijke overeenkomst. ${ }^{34}$ Dit terwijl de strafbeschikking door de wetgever is aangemerkt als een daad van vervolging. ${ }^{35}$ Er lijkt dus sprake te zijn van een principiële afwijking ten opzichte van de transactie, die er juist toe strekt te voorkomen dat een vervolging plaatsvindt en een strafzaak voor de rechter wordt

30. Voor de categorie onder (a) is nog vereist dat deze voorwaarde niet voortvloeit uit door het College van procureurs-generaal vastgestelde richtlijnen voor strafvordering en er evenmin sprake is van een transactie als bedoeld in art. 74a $\mathrm{Sr}$.

31. In art. 178a lid $1 \mathrm{Sr}$ worden personen in de openbare dienst van een vreemde staat (of van een volkenrechtelijke organisatie) ten aanzien van art. $177 \mathrm{Sr}$ gelijkgesteld met (Nederlandse) ambtenaren.

32. Kritisch hierover is Hofstee (2017, p. 34), die pleit voor een meer uitgebreide motivering van de keuze voor buitengerechtelijke afdoening.

33. Stb. 2006, 330; bij Stb. 2008, 4 in werking getreden. Zie nader E. Sikkema \& F.G.H. Kristen, 'Strafbeschikking en ZSM. Verschuivingen binnen de strafrechtshandhaving', in: F. de Jong, R.S.B. Kool (red.), Relaties van gezag en verantwoordelijkheid: strafrechtelijke ontwikkelingen, Den Haag: Boom Lemma 2012, p.185-189.

34. Zie o.m. P. Osinga, Transactie in strafzaken, Arnhem: Gouda Quint 1992, p. 198-199; J.H. Crijns, De strafrechtelijke overeenkomst, Deventer: Kluwer 2010, p. 36-40, 173-182. Van Roomen \& Verbruggen (2015, p. 229-230) merken overigens op dat de transactie in de praktijk het resultaat is van uitgebreide onderhandelingen en daarmee veeleer het karakter heeft van een schikking dan van voorwaarde(n) ter voorkoming van verdere vervolging.

35. Zie het titelopschrift 'Titel IVA: Vervolging door strafbeschikking' en Kamerstukken II 2004-2005, 29 849, nr. 3, p. 15-17. gebracht. ${ }^{36}$ De bestraffing door middel van een strafbeschikking moet daarbij zijn gebaseerd op de vaststelling van schuld aan een strafbaar feit. ${ }^{37}$

De wetgever sprak destijds van een 'omvorming' en 'overgang' van de transactie in en naar de strafbeschikking. De bedoeling was dat de transactie uiteindelijk in het geheel zou komen te vervallen. ${ }^{38} \mathrm{Er}$ werd echter besloten de strafbeschikking gefaseerd in te voeren. ${ }^{39}$ Het gedeelte van de wet dat artikel $74 \mathrm{Sr}$ zou doen vervallen, trad vooralsnog niet in werking. ${ }^{40}$ Daarom bestaan deze twee vormen van buitengerechtelijke afdoening sindsdien (en tot op heden) naast elkaar. Het OM kan dus in beginsel zowel een transactie overeenkomen met de verdachte als een strafbeschikking jegens hem uitvaardigen. De 'Aanwijzing OM-strafbeschikking' bepaalt echter dat alle strafzaken die zich daarvoor lenen in beginsel door middel van een strafbeschikking worden afgedaan. Alleen als sprake is van een contraindicatie kan nog steeds een transactie worden angeboden. De Aanwijzing geeft een niet-limitatief overzicht van contra-indicaties, waarbij vooral in het oog springt dat in politiek of publicitair gevoelige zaken slechts bij hoge uitzondering een strafbeschikking kan worden uitgevaardigd.$^{41}$ Voor deze categorie gevallen wordt verwezen naar de 'Aanwijzing hoge en bijzondere transacties' (zie paragraaf 3.1). Voor de 'reguliere' transactie lijkt het einde echter in zicht; het aantal transacties is sinds 2010 dan ook sterk afgenomen. ${ }^{42}$

\subsection{De praktijk}

Hoewel de strafbeschikking ondertussen de transactie in aantallen zaken heeft ingehaald ${ }^{43}$ is de transactie allesbehalve een papieren tijger geworden. Het OM lijkt deze manier van afdoening te hebben herontdekt als manier om omvangrijke zaken af te doen. Typerend zijn de eerder genoemde recordovereenkomsten in de zaken van SBM Offshore, Vimpelcom en TeliaSonera. De 'hoge transactie' is in Nederland - in navolging van de VS - een belangrijk instrument geworden om (buitenlandse) omkopingsaffaires en andere grote zaken af te doen. ${ }^{44}$ Op deze manier worden buitengerechtelijk tien-

36. Zie o.m. artikel 74 lid 1 Sr; Kamerstukken II 2004-2005, 29 849, nr. 3, p. 3, 15.

37. Zie Kamerstukken II 2004-2005, 29 849, nr. 3, p. 2, 31, 54, 73, 76.

38. Zie bijvoorbeeld Kamerstukken // 2004/05, 29849, 3, p. 6, 62, 88 $(\mathrm{MvT})$, waar de minister onder andere opmerkt dat de transactie 'nog enige tijd' naast de strafbeschikking zou blijven bestaan.

39. Zie artikel XXII Wet OM-afdoening, waarover Kamerstukken I/ 2004 2005, 29849 , nr. 3, p. 88.

40. Artikel II, onderdeel O van Stb. 2006, 330 is bij Stb. 2008, 4 nog niet in werking getreden.

41. Stcrt. 2017, 42314.

42. Vriend 2016, p. 194, onder verwijzing naar het Jaarbericht 2014 van het OM.

43. G.J.M. Corstens, Het Nederlands strafprocesrecht, bewerkt door M.J. Borgers, Deventer: Kluwer 2014, p. 14 en F.P. van Tulder, R.F. Meijer \& S.N. Kalidien, 'Van schikking naar strafbeschikking? Een eerste balans', NJB 2017, p. 383-392.

44. D. Zivkovic, 'Omgaan met omkopingsincidenten: intern onderzoek en afdoening', TvS\&O 2017, p. 211. Overigens wordt jaarlijks door het OM 'maar een tiental' transacties van meer dan 50.000 euro afgesloten, aldus toenmalig rechercheofficier bij het Functioneel Parket Rutger Jeuken in Opportuun 2017, nr. 4, p. 27 
tallen miljoenen euro's geïnd voor de Nederlandse Staat. Het is dan ook zeer de vraag of deze consensuele rechtsfiguur in dit soort gevallen gemist kan worden. ${ }^{45}$

Het belang om te 'schikken' is voor beide partijen evident. Het OM kan met een transactie snel een voorbeeld stellen; de normhandhaving en generale preventie zijn daarmee gediend. ${ }^{46}$ Voor een onderneming heeft een transactie als onmiskenbaar voordeel dat een langdurig strafrechtelijk proces - met veel publiciteit, onzekerheid en kosten - kan worden vermeden. De kwestie kan in een relatief korte tijd worden afgesloten en de onderneming kan zich richten op een (meer) integere bedrijfsvoering. Volgens Zivkovic (advocaat bij Heineken) is verder relevant dat een transactie formeel geen erkenning van schuld of veroordeling inhoudt en dat een veroordeling door een strafrechter wordt voorkomen. Dat is vooral belangrijk voor bedrijven die commercieel afhankelijk zijn van hun reputatie. ${ }^{47}$ Bovendien staat een transactie inzake corruptie niet in de weg aan participatie in Europese overheidsaanbestedingen, dit in tegenstelling tot een corruptieveroordeling. ${ }^{48}$ Vanuit het perspectief van het $\mathrm{OM}$ en de samenleving is aantrekkelijk dat het gaat om (zeer) aanzienlijke transacties, terwijl een rechtspersoon ook in een strafproces slechts een geldboete (en geen gevangenisstraf) kan worden opgelegd. Daarnaast kleven er voor het OM ook risico's aan een strafproces en bijbehorende executie. ${ }^{49}$ Dit maakt een transactie (ook) voor het $\mathrm{OM}$ tot een efficiënte en effectieve afdoeningsmodaliteit: 'In plaats van een langdurig en kostbaar onderzoek en procedure kan in een vrij kort tijdsbestek een schikkingsbedrag worden overeengekomen waarvan het de vraag is of dat ook in een procedure door een rechter zou worden opgelegd. De maximum geldboetes worden zelden opgelegd en de mogelijkheid om geldboetes in geval van meerdere strafbare feiten onbeperkt te laten cumuleren, blijft in de regel ook onbenut. ${ }^{50}$ Verder kan het $\mathrm{OM}$ in het kader van een transactie een pakket aan specifieke 'tailormade' maatregelen met de onderneming overeenkomen, met name ter voorkoming van onregelmatigheden in de toekomst (zoals versterking van het compliance-programma, verbetering van bedrijfsprocessen en integriteitsprocedures). ${ }^{51}$ Van Roomen en Verbruggen (destijds beiden advocaat) merken op dat de te stellen voorwaar-

45. Vgl. Vriend 2016, p. 194; Van Roomen \& Verbruggen 2015, p. 229. Overigens kent ook de strafbeschikking wel degelijk consensuele elementen; zie Sikkema \& Kristen 2012, p. 198.

46. C.M.I. van Asperen de Boer \& M.L. van Duijvenbode, 'Openheid in schikkingspraktijk OM', NJB 2015, p. 21-22.

47. Zivkovic 2017, p. 220

48. Directive 2014/24/EU of the European Parliament and of the Council of 26 February 2014 on public procurement, art. 100

49. Vgl. Van Roomen \& Verbruggen 2015, p. 229.

50. Zivkovic 2017, p. 220. De auteur wijst ook nog op de recente verhoging van het boetemaximum tot $10 \%$ van de jaaromzet en vraagt zich af of dat in de praktijk veel zal uitmaken.

51. Zivkovic 2017, p. 220-221. De auteur noemt verder nog de verplichting tot overdracht van onderzoeksresultaten, medewerking aan een perspublicatie ter publieke verantwoording, acceptatie van de vastgestelde feiten of het aanstellen van een onafhankelijke compliance monitor die rapporteert aan het $\mathrm{OM}$ over de naleving door de onderneming van gemaakte afspraken. den weliswaar limitatief zijn omschreven in artikel 74 $\mathrm{Sr}$, maar dat de praktijk 'creatief' is en dat dikwijls andere voorwaarden worden opgenomen dan de wet 'strikt genomen' toelaat. ${ }^{52}$

Mede naar aanleiding van maatschappelijke kritiek (zie hierna) betracht het OM steeds meer openheid omtrent transacties, zoals blijkt uit de steeds uitgebreidere (feitenrelazen bij) persberichten. Aldus wordt tegemoetgekomen aan de roep om meer openbaarheid en wordt ook de controleerbaarheid en aanvaardbaarheid van transacties vergroot. In zekere zin kan zo het ontbreken van een openbare behandeling ter terechtzitting (deels) worden gecompenseerd. ${ }^{53}$ Uit de persberichten van het OM kan volgens Hofstee een zekere lijn worden afgeleid als het gaat om de overwegingen die ten grondslag liggen aan het aanbieden van een transactie (in buitenlandse corruptiezaken). In de eerste plaats gaat het veelal om ondernemingen die de misstanden zelf gemeld hebben bij het OM. Een tweede belangrijke factor is dat de bedrijven medemerking verleend hebben aan het opsporingsonderzoek. Het gaat dan om gevallen waarin een intern onderzoek heeft plaatsgevonden en de resultaten daarvan met de autoriteiten zijn gedeeld. Ook 'schoon schip maken', bijvoorbeeld door de directie van de onderneming te vervangen, is een terugkerend thema. Daarnaast is de aanscherping of meer strikte naleving van compliance-maatregelen - en daarmee het inrichten van de bedrijfsvoering op preventie van misstanden in de toekomst - een belangrijke factor. Tot slot kan een rol spelen of een onderneming publiekelijk verantwoordelijkheid neemt voor de strafbare feiten. ${ }^{54}$ De genoemde factoren zijn zeer vergelijkbaar met de voorwaarden die in de VS worden gehanteerd om tot een schikking over te gaan. ${ }^{55}$ Hoewel zelfmelding dus wordt gezien als een belangrijke reden om een transactie aan te bieden (en slechts strafvervolging in te stellen tegen individuen), worden overigens ook zaken met een transactie afgedaan waarin niet vrijwillig melding is gedaan (zoals in het geval van Vimpelcom). ${ }^{56}$ Een factor die in de Nederlandse transactiepraktijk tot op heden nog geen rol speelt, maar die in de VS wel aan de orde is, betreft de compensatie van de slachtoffers van buitenlandse corruptie (zie verder paragraaf 5).

Opvallend is dat de hier beschreven handhavingspraktijk wezenlijk afwijkt van de toepasselijke 'Aanwijzing opsporing en vervolging ambtelijke omkoping in het buitenland'. ${ }^{57}$ Daarin wordt benadrukt dat omkoping een ernstig misdrijf is, dat de integriteit van de overheid ernstig aantast en tot grote schade kan leiden. In inter-

52. Van Roomen \& Verbruggen 2015, p. 229. Een strafbeschikking kan overigens ook aanwijzingen bevatten die het gedrag van de verdachte betreffen, maar deze zijn gebonden aan een maximale proeftijd van een jaar (zie art. 257a lid 3 sub e Sv).

53. Zivkovic 2017, p. 221. Zie ook het interview met toenmalig rechercheofficier bij het Functioneel Parket Rutger Jeuken in Opportuun 2017, nr. 4, p. 28.

54. Hofstee 2017, p. 29-30

55. Hofstee 2017, p. 31-33.

56. Zivkovic 2017, p. 220

57. Stcrt. 2012, 26939. 
nationaal verband is afgesproken dat buitenlandse corruptie streng moet worden aangepakt. De 'grondhouding' ten aanzien van vervolging dient dan ook positief te zijn. De factoren die op grond van deze Aanwijzing meewegen bij de beoordeling van de opportuniteit van vervolging vertonen bovendien weinig overeenkomsten met de daadwerkelijke afdoening van buitenlandse corruptiezaken. Zo is de aanzienlijke omvang van de steekpenningen volgens de Aanwijzing een reden om tot vervolging over te gaan, terwijl het in de getransigeerde zaken ging om tientallen miljoenen. Ook andere factoren (de positie van de omgekochte ambtenaren, de mate van concurrentievervalsing, de mogelijkheid van verder onderzoek en de kans op succesvolle vervolging) duiden erop dat vervolging in deze gevallen juist voor de hand zou hebben gelegen. De mogelijkheid om te transigeren wordt in de Aanwijzing zelfs helemaal niet genoemd. De redenen die het $\mathrm{OM}$ in de praktijk hanteert om tot een transactie over te gaan - en daarmee de invulling van de 'goede reden' om af te wijken van de 'grondhouding' dat vervolgd moet worden - zal men daarin dan ook tevergeefs zoeken. ${ }^{58}$ Dat is anders in de VS, waar de concrete factoren die bepalen onder welke omstandigheden een rechtspersoon in aanmerking komt voor een schikking (volledige medewerking met het onderzoek, effectieve compliance-programma's, zelfmelding, herstelmaatregelen) gedetailleerd zijn vastgelegd. ${ }^{59}$

\subsection{De kritiek}

De ontstane praktijk van omvangrijke transacties is in de literatuur op kritiek gestuit. ${ }^{60}$ Betoogd is dat de transactiepraktijk zich grotendeels onttrekt aan de (externe) openbaarheid en aan de controle door de rechter. Dat roept vragen op over de legitimiteit van dergelijke transacties. ${ }^{61}$ De kritiek ziet in de eerste plaats dus op het ontbreken van een openbare terechtzitting en daarmee van publieke verantwoording. Doordat geen inhoudelijke beoordeling door een rechter plaatsvindt, onttrekken belangrijke rechtsvragen zich aan het oordeel van de rechter, hetgeen de rechtsontwikkeling zou ondermijnen. Verder speelt in de discussie over schikkingen het risico van klassenjustitie een belangrijke rol. Tot slot zou het risico van machtsmisbruik van het OM bestaan, omdat verdachten onder grote druk staan om een openbare terechtzitting te voorkomen en daarom in te stemmen met een transactievoorstel. De ongelijke verhouding tussen $\mathrm{OM}$ en verdachte zou daarbij een rol spelen. ${ }^{62} \mathrm{De}$ machtspositie van het OM wordt overigens gecompenseerd doordat de verdachte zich kan laten bijstaan door

58. Hofstee 2017, p. 31.

59. A Resource Guide to the U.S. Foreign Corrupt Practices Act, p.74. Deze handleiding is te raadplegen op https://www.justice.gov/sites/default/ files/criminal-fraud/legacy/2015/01/16/guide.pdf (laatst bezocht op 27 april 2018)

60. Zie Vriend 2016, p. 197-199, voor een uitgebreid overzicht van de opvattingen in de literatuur.

61. Vriend 2016, p. 195 en p. 197

62. N.G.H. Verschaeren \& A.B. Schoonbeek, 'Geschikt en gewogen; streeft roep om rechterlijke toetsing van transacties doel voorbij?', TBS\&H 2015, p. 191. een raadsman. ${ }^{63}$ Vanwege de genoemde bezwaren is er discussie of er niet een vorm van rechterlijke toetsing moet worden gekoppeld aan het instituut van de transactie (zie verder paragraaf 4$).{ }^{64}$

Omvangrijke transacties in grote fraude- en corruptiezaken liggen ook maatschappelijk gevoelig. In Nederland zorgen dergelijke schikkingen voor veel verontwaardiging en onbegrip vanuit de samenleving. Transacties met grote bedrijven hebben geleid tot negatieve publiciteit en vervolgens ook tot Kamervragen. ${ }^{65}$ Critici stellen dat ondernemingen 'vervolging afkopen' en 'makkelijk wegkomen'. ${ }^{66}$ Anderzijds zou juist het risico bestaan dat transacties worden aangeboden in bewijstechnisch zwakke zaken, waarin een veroordeling bewijsrechtelijk niet haalbaar zou zijn. ${ }^{67}$ 'De maatschappij heeft geen zicht op wat zich in de achterkamertjes heeft afgespeeld en de rechter staat buitenspel en kan geen juridisch oordeel geven over toch juist zo belangrijke zaken. ${ }^{68}$ Zoals gezegd probeert het OM door middel van meer uitgebreide en gedetailleerde persberichten tegemoet te komen aan het gebrek aan transparantie. ${ }^{69}$ Een ander punt van zorg is de vervolging van natuurlijke personen nadat met een bedrijf geschikt is. De schijn zou bestaan dat vervolging van leidinggevers achterwege blijft als 'wisselgeld' voor de hoge transactie die door de onderneming is betaald. ${ }^{70}$ De voorzitter van de Raad voor de rechtspraak heeft in het Jaarverslag 2016 gepleit voor een beperking van buitengerechtelijke afdoening tot de standaardmatige afdoening van veelvoorkomende kleine zaken. Als het OM extreem grote strafzaken afdoet met een miljoenentransactie kan de samenleving maar zeer ten dele zien en controleren dat er recht wordt gedaan. Die transactie kan niet door de rechter op juistheid worden getoetst. ${ }^{71}$

Specifiek voor omkopingszaken stelt Hofstee dat de 'Aanwijzing opsporing en vervolging ambtelijke omko-

63. Verschaeren \& Schoonbeek 2015, p. 204

64. C.M.I. van Asperen de Boer \& M.L. van Duijvenbode, 'Schikkingscultuur in fraudezaken ondermijnt de rechtsontwikkeling', NJB 2014, p. 641-646; B.F. Keulen, 'Strafrechter en consensualiteit', DD 2014, p. 739-749; Verschaeren \& Schoonbeek 2015, p. 190-205; J.H. Crijns \& R.S.B. Kool, 'Afscheid van de klassieke strafrechtelijke procedure', in: L. Coenraad e.a. (red.), Afscheid van de klassieke procedure? (preadviezen NJV), Deventer: Wolters Kluwer 2017, p. 329-331.

65. Zie recent nog de uitzending van het televisieprogramma Zembla ('Zakendoen met justitie', 27 februari 2018) over dit onderwerp (https://zembla.bnnvara.nl/nieuws/komende-uitzending-zakendoenmet-justitie). Naar aanleiding van deze uitzending werden Kamervragen gesteld door het lid Van Nispen (https://zembla.bnnvara.nl/nieuws/ kamervragen-na-uitzending-zembla-over-schikkingen).

66. Zivkovic 2017, p. 220. De auteur verwijst onder meer naar het gesprek met Corstens in het televisieprogramma Buitenhof.

67. Vriend 2016, p. 197, eveneens onder verwijzing naar Corstens in Buitenhof.

68. C.M.I. van Asperen de Boer \& M.L. van Duijvenbode, 'Openheid in schikkingspraktijk OM', NJB 2015, p. 21.

69. Vgl. Van Asperen de Boer \& Van Duijvenbode 2015, p. 21.

70. Van Asperen de Boer \& Van Duijvenbode 2015, p. 22. Dit punt kwam ook aan de orde in de eerder genoemde uitzending van Zembla. In die uitzending werd door de hoofdofficier van justitie van het Functioneel Parket gesteld dat in transacties geen afspraken (meer) worden gemaakt over het niet vervolgen van natuurlijke personen.

71. F. Bakker, 'Jaarbericht', Jaarverslag Rechtspraak 2016, te raadplegen via www.jaarverslagrechtspraak.nl/pagina/jaarbericht. 
ping in het buitenland' niet aansluit op de praktijk. Nederland zou hier een voorbeeld moeten nemen aan de VS, waar de relevante factoren en voorwaarden zeer inzichtelijk zijn gemaakt. Een praktisch voordeel daarvan kan zijn dat corruptie eerder ontdekt wordt en de handhaving versterkt, nu zelfmelding en medewerking aan het onderzoek voor een bedrijf aantoonbaar voordelen heeft (namelijk het ontlopen van een strafrechtelijke vervolging). Deze factoren zouden ook kunnen worden meegewogen bij het bepalen van de hoogte van het transactiebedrag. Openheid over deze voorwaarden zou daarnaast kunnen bijdragen aan meer begrip voor 'megaschikkingen' in de maatschappij. ${ }^{72}$ Overigens lijkt zelfmelding in de praktijk niet altijd tot lagere sancties te leiden; ook na een vrijwillige melding worden vrijwel altijd 'torenhoge schikkingsbedragen' betaald. Ook om die reden zou het volgens verschillende auteurs goed zijn als het OM richtsnoeren zou publiceren omtrent de afdoening van corruptiezaken, inclusief de criteria voor vrijwillige melding en samenwerking en de 'strafkorting' die de verdachte onderneming kan krijgen indien daaraan is voldaan. ${ }^{73}$ Overigens moet worden gewaakt voor al te forse strafkortingen, aangezien deze de druk op de verdachte om in te stemmen met de transactie kunnen verhogen. ${ }^{74}$ Ten aanzien van de strafbeschikking bepaalt de 'Aanwijzing OM-strafbeschikking' om die reden dat ter terechtzitting in beginsel geen zwaardere sanctie wordt geëist dan de sanctie van de strafbeschikking. ${ }^{75}$

\section{De toekomst (I): rechterlijke toetsing van hoge en bijzondere transacties?}

De huidige plannen ter modernisering van het Wetboek van Strafvordering brengen (nog) geen verandering aan in de regeling van de strafbeschikking en de transactie. ${ }^{76}$ Om praktische redenen is ervoor gekozen om de regeling van de buitengerechtelijke afdoening inhoudelijk ongewijzigd in het wetsvoorstel voor een nieuw Boek 3 op te nemen, nu het voor een belangrijk deel recente wetgeving betreft (met name de Wet OM-afdoening). Eventuele wetswijzigingen zouden pas aan de orde zijn na de (nog niet afgeronde) evaluatie van de Wet OMafdoening. Dat geldt ook voor de wensen die door de Raad voor de rechtspraak zijn geuit ten aanzien van een mogelijk in te voeren rechterlijke toetsing van transacties en strafbeschikkingen. Wenselijk geachte wijzigingen die voortvloeien uit de bedoelde evaluatie kunnen in een later stadium (na de consultatie over Boek 3) - maar wel in het kader van de modernisering van het wetboek - worden meegenomen. Dan zal ook een beslissing

72. Hofstee 2017, p. 33-34

73. Zivkovic 201, p. 218; Van Roomen \& Verbruggen 2015, p. 226-227 en p. 233.

74. Vriend 2016, p. 198.

75. Stcrt. 2017, 42314, p. 1.

76. Zie Kamerstukken I/ 2015/16, 29279, 278 (Contourennota), p. 69. worden genomen over het al dan niet handhaven van de bestaande figuur van de transactie en de verplaatsing daarvan naar het Wetboek van Strafvordering. ${ }^{77}$ Een fundamentele vraag die nog beantwoord moet worden is kortom of het nieuwe wetboek moet voorzien in een vorm van rechterlijke toetsing van hoge transacties en strafbeschikkingen.

Door verschillende auteurs is geopperd om een (marginale) rechterlijke toets van een megatransactie te introduceren. ${ }^{78}$ Dit in verband met de oplopende hoogte van de schikkingsbedragen (die inmiddels de omvang van Amerikaanse schikkingen zou benaderen) en ter bescherming van de betreffende verdachte. In dit verband wordt vaak verwezen naar de bestaande praktijk in de VS. 'Amerikaanse praktijken ook hier te lande vragen misschien wel om Amerikaanse oplossingen', zo is opgemerkt. ${ }^{79}$ Er wordt wel gesteld dat een dergelijke rechterlijke toetsing in de VS en het Verenigd Koninkrijk (VK) mede bijdraagt aan een hogere maatschappelijke acceptatie. Ook zou dit de politieke gevoeligheid verminderen van het aangaan van hoge transacties, hetgeen nu immers onder verantwoordelijkheid van de Minister van Justitie en Veiligheid gebeurt. ${ }^{80}$ Als het gaat om de praktijk in de VS moet overigens onderscheid worden gemaakt tussen de 'Deferred Prosecution Agreement' (DPA) en de 'Non Prosecution Agreement' (NPA). Bij een DPA dient de Department of Justice (DoJ) een verzoek in bij de rechtbank om de vervolging uit te stellen, indien de verdachte zich gedurende een bepaalde periode aan de overeengekomen voorwaarden houdt. Nadat de rechter de overeenkomst heeft goedgekeurd, wordt deze (door middel van een persbericht) openbaar gemaakt. Anders dan in het geval van een DPA wordt een NPA niet aan een rechter voorgelegd, maar betreft het enkel een afspraak tussen de verdachte en de DoJ of de Securities and Exchange Commission (SEC). ${ }^{81}$

Vriend heeft voorgesteld om een aparte openbare (raadkamer)procedure in te voeren voor de toetsing van hoge en bijzondere transacties. Bij dergelijke transacties dient volgens deze auteur een onafhankelijke controle plaats te vinden op de rechtmatigheid daarvan. ${ }^{82}$ Een openbare behandeling zal weliswaar een categorie verdachten afschrikken om een transactie aan te gaan; zij willen immers zoveel mogelijk vermijden dat de zaak in de publiciteit komt. Dit kan een negatieve invloed hebben op het gebruik van hoge transacties in de praktijk, maar het alternatief is voor de verdachte ook weinig aantrek-

77. Voorstel van Wet tot vaststelling van Boek 3 van het nieuwe Wetboek van Strafvordering inhoudende bepalingen over beslissingen omtrent vervolging in verband met de modernisering van het Wetboek van Strafvordering (Vaststellingswet Boek 3 van het nieuwe Wetboek van Strafvordering (Beslissingen omtrent vervolging)), memorie van toelichting, p. 3 en p. $25-26$.

78. Zie o.a. Van Roomen \& Verbruggen 2015, p. 233-234; T.R. van Roomen \& A. Verbruggen, 'Internationale trends in preventie, detectie en repressie van corruptie', TVS\&O 2017, nr. 4, p. 157.

79. Van Asperen de Boer \& Van Duijvenbode 2015, p. 22, die verwijzen naar uitspraken van Corstens in het televisieprogramma Buitenhof.

80. Zivkovic 2017, p. 221

81. Hofstee 2017, p. 32.

82. Vriend 2016, p. 202. 
kelijk: een openbare terechtzitting die kan leiden tot een vaststelling van schuld. De raadkamer zou met name aan drie criteria moeten toetsen. In de eerste plaats moet de rechter nagaan of de verdachte vrijwillig heeft ingestemd met de voorwaarden die in de transactie zijn opgenomen. Ten tweede moet de raadkamer toetsen of de verdachte voldoende geinformeerd is over de inhoud van de transactie en de rechtsgevolgen van het accepteren daarvan. Tot slot dient de rechter te beoordelen of het dossier 'prima facie' voldoende bewijs bevat om tot een bewezenverklaring te kunnen komen. Het zou hier moeten gaan om een marginale toetsing, aangezien een volle toetsing gelijk zou staan aan een behandeling van de zaak ter terechtzitting. ${ }^{83}$

Volgens tegenstanders zou een rechterlijke toets echter afbreuk doen aan de effectiviteit van buitengerechtelijke afdoening. Ook zou het gevaar bestaan dat de rechter zich gaat buigen over opportuniteitsvraagstukken. ${ }^{84}$ In de VS wordt de kwaliteit van de rechterlijke toetsing van de DPA betwist. Rechters zouden al snel hun 'stempel' onder een DPA zetten, zonder inhoudelijk naar de essentie van de overeenkomst te kijken. Procesdeelnemers zijn ontevreden over de rol van de rechter, onder meer vanwege de onduidelijkheid omtrent diens bevoegdheden in dit proces. Wettelijke criteria voor de rechterlijke toetsing van een DPA ontbreken. ${ }^{85}$ Hofstee stelt dan ook terecht dat de bezwaren die in de VS zijn geuit moeten worden meegenomen in de discussie over de introductie van een rechterlijke toets. ${ }^{86}$ Ook Verschaeren en Schoonbeek merken op dat rechters in de VS voorheen vrij terughoudend waren bij de toetsing en dat deze meestal een 'hamerstuk' was. Mede naar aanleiding van kritiek op deze praktijk lijkt een aantal rechters DPA's in toenemende mate inhoudelijk te toetsen. Het toetsingskader blijft echter onduidelijk en het is onzeker of alle rechters bereid zijn om tot een inhoudelijke toetsing over te gaan. Dat leidt tot rechtsonzekerheid bij verdachten, waardoor de bereidheid om zelf overtredingen te melden kan afnemen. Verschaeren en Schoonbeek menen dat rechterlijke toetsing een deel van de bezwaren tegen hoge transacties kan wegnemen, maar dat aan het Amerikaanse systeem weer andere belangrijke bezwaren kleven en dat dit systeem daarom geen aantrekkelijk alternatief is voor Nederland. ${ }^{87}$ Crijns en Kool merken eveneens op dat moet worden voorkomen dat een rechter in dit soort gevoelige zaken verwordt tot een stempelmachine. Toch achten zij invoering van een (marginale) rechterlijke toets van de voorgenomen transactie verstandig, met name met het oog op de maatschappelijke aanvaardbaarheid van deze afdoening. ${ }^{88}$ Onze verwachting is dat de discussie hierover de komende jaren nog wel even zal voortduren in het kader

\footnotetext{
83. Vriend 2016, p. 202-204.

84. Verschaeren \& Schoonbeek 2015, p. 203-205.

85. Hofstee 2017, p. 34-35; Verschaeren \& Schoonbeek 2015, p. 198-201.

86. Hofstee 2017, p. 34-35

87. Verschaeren \& Schoonbeek 2015, p. 198-201. Ten aanzien van het systeem in het VK komen de auteurs tot een vergelijkbare conclusie (Verschaeren \& Schoonbeek 2015, p. 201-203).

88. Crijns \& Kool 2017, p. 329-330.
}

van de modernisering van de strafvordering. Wij menen dat er zeker aanleiding bestaat om maatregelen te treffen die tegemoetkomen aan de eerdergenoemde bezwaren tegen de huidige transactiepraktijk in corruptiezaken, maar mede gezien de ervaringen in de VS betwijfelen wij of een rechterlijke toetsing van hoge transacties (en strafbeschikkingen) naar Amerikaans model de meest aangewezen oplossing is. De behoefte aan rechterlijke controle zal naar verwachting afnemen naarmate de transactiebevoegdheid door andere maatregelen - zoals meer transparantie, minder onderhandelingsruimte en schulderkenning als verplichte voorwaarde ${ }^{89}-$ (verder) aan banden wordt gelegd.

\section{De toekomst (II): compensatie van slachtoffers?}

Uit de toename van het aantal transacties ter zake van buitenlandse corruptie en de hoogte daarvan vloeit zoals gezegd voort dat er de komende jaren een groeiende behoefte zal zijn aan richtlijnen voor de hoogte van 'straffen'. Daarbij rijst ook de vraag hoe de inkomsten uit handhavingsacties besteed dienen te worden. Tot nu toe vloeien de transactiegelden in Nederland in de staatskas of in de begroting van het ministerie van Justitie en Veiligheid. Nu de bedragen echter steeds hoger worden, komen er ook steeds meer vragen over de wenselijkheid en rechtvaardigheid daarvan. Uitgangspunt is immers dat het compenseren van slachtoffers prevaleert boven het incasseren van transacties en ontnemingen. ${ }^{90}$ Vanwege de tegelijkertijd toenemende aandacht voor de positie van het slachtoffer in het strafproces, ${ }^{91}$ is het potentieel compenseren van slachtoffers van buitenlandse corruptie een onderwerp waarbinnen wij de komende jaren ontwikkelingen verwachten.

Vanuit het perspectief van Nederlands straf(proces)recht wordt omkoping wel een slachtofferloos delict genoemd, omdat er van een aanwijsbaar concreet en rechtstreeks slachtoffer veelal geen sprake is. ${ }^{92}$ In internationale anticorruptiegremia is echter een groeiende consensus zichtbaar dat omkoping wel degelijk slachtof-

89. Zie de eerder aangehaalde uitspraken van de hoofdofficier van het Functioneel Parket in de uitzending van Zembla en in andere media (voetnoten 25 en 71).

90. Dit past in de systematiek van artikel $36 \mathrm{f}$ Strafrecht betreffende de schadevergoedingsmaatregel. Zie lid 4 van dit artikel: betalingen door de veroordeelde aan de staat verricht, strekken in de eerste plaats tot voldoening van de maatregel en vervolgens tot voldoening van een opgelegde boete.

91. Zie hierover bijvoorbeeld Justitiële verkenningen 2015, nr. 5, Mensbeelden in het strafrecht, Boom Juridische uitgevers 2015, inleiding: 'Ook het slachtoffer is onmiskenbaar niet meer wat hij is geweest. Werden slachtoffers lange tijd zo goed als genegeerd in het strafproces, tegenwoordig lijkt het slachtoffer uitgegroeid tot een geëmancipeerde drager van rechten die voor zichzelf een eigen positie opeist.'

92. E. Sikkema, Ambtelijke corruptie in het strafrecht. Een studie over omkoping en andere ambtsdelicten (diss. Groningen), Den Haag: Boom Juridische uitgevers 2005, p. 552 e.v. 
fers heeft. ${ }^{93}$ Dit kunnen concurrerende bedrijven zijn die schade oplopen doordat zij een overheidsopdracht mislopen, maar ook een samenleving als geheel kan gezien worden als slachtoffer van corruptie. Als in een land overheidsopdrachten aan multinationale bedrijven worden toegekend op basis van omkoping, betekent dit namelijk dat overheidsgeld in dat land niet efficiënt besteed wordt en dat er minder geïnvesteerd kan worden in algemene voorzieningen zoals onderwijs, gezondheidszorg en infrastructuur. ${ }^{94}$ In de zaak Vimpelcom kan bijvoorbeeld de gehele Oezbeekse bevolking als slachtoffer van corruptie beschouwd worden, omdat Vimpelcom er door de omkoping in slaagde voor zichzelf exclusieve toegang te creëren tot de Oezbeekse telecommarkt, waardoor de gehele Oezbeekse bevolking tot op de dag van vandaag te veel betaalt voor telecommunicatie.

Over het antwoord op de vragen of en hoe de slachtoffers gecompenseerd kunnen worden, bestaat minder eensgezindheid. Het $\mathrm{UNCAC}^{95}$ biedt de mogelijkheid om schadevergoeding toe te kennen aan staten (artikel 53), personen of andere entiteiten (artikel 35) en/of ontwikkelingsprojecten (artikel 63). Er zijn echter geen richtlijnen over welke procedure in welke situatie de voorkeur heeft, of in het algemeen over de wijze waarop slachtoffers geidentificeerd kunnen worden, hoe de schade berekend kan worden en evenmin over de voorwaarden die aan schadevergoedingsmaatregelen gesteld kunnen.

In de VS is het sinds de inwerkingtreding van de FCPA enkele keren voorgekomen dat buitenlandse staten schadevergoeding ontvingen voor in hun land gepleegde corruptie. ${ }^{96}$ Het ging in al deze gevallen om relatief kleine bedragen van enkele honderdduizenden dollars en in de meeste gevallen ging het om een schikkingsvoorwaarde, niet om een rechterlijke beslissing. Met het oplopen van de schikkingsbedragen nam in de VS de weerstand toe tegen betalingen aan buitenlandse staten. In de zaak Alcatel-Lucent in 2010 werd een nieuw standpunt ingenomen, dat sindsdien vast Amerikaans beleid is: de VS betaalt geen compensatie aan corrupte overheden die zelf hebben bijgedragen aan het strafbare feit waardoor schade is ontstaan. ${ }^{97}$ Dit standpunt werd in datzelfde jaar ook verwoord in OECD-rapport over de VS. ${ }^{98}$

93. Zie in dit verband bijvoorbeeld de kritiek van de OECD working group on bribery op Australië in het Phase 4 rapport van december 2017, p. 164.

94. K. Moyo, 'An analysis of the impact of corruption on the realisation of the right to development', South African Journal on Human Rights, Volume 33, 2017 - Issue 2.

95. Verdrag van de Verenigde Naties tegen corruptie; New York, 31 oktober 2003, Trb. 2005, 244.

96. United States of America v. Kenny International Corp., et al. 1979; United States of America v. Richard H. Liebo ('Napco') 1989; United States of America v. F.G. Mason Engineering, Inc., et al. 1990; United States of America v. Juan Diaz 2009; United States of America v. Gerald Green, et al. 2010.

97. Securities and Exchange Commission v. Alcatel-Lucent, S.A. 2010

98. Phase 3 report on implementing the OECD anti-bribery convention in the United States, p. 155.
Niet alleen in de VS is deze kwestie aan de orde, maar ook in het Verenigd Koninkrijk ${ }^{99}$ en Zwitserland. ${ }^{100}$ In Nederland hebben zich voor zover ons bekend nog geen buitenlandse staten of andere slachtoffers gemeld, maar het is waarschijnlijk een kwestie van tijd tot het onderwerp van compensatie voor slachtoffers zich hier in een concrete zaak voordoet. Gezien de door ons geschetste tendens van buitengerechtelijke afdoening, wordt de vraag dan niet zozeer hoe kansrijk een civiele zaak of een voeging als benadeelde partij is, maar op welke manier er in transactievoorwaarden recht gedaan kan worden aan potentiele slachtoffers. Wij verwachten dat het Nederlandse Openbaar Ministerie (OM) zich, in navolging van het Amerikaanse standpunt, zal verzetten tegen het betalen van schadevergoeding aan de staat waar de omkoping plaatsvond. De vraag is dan welke andere mogelijkheden er zijn.

Een deel van het transactiebedrag rechtstreeks investeren in ontwikkelingsprojecten - door het OM of als opdracht aan het bedrijf, zonder tussenkomst van de betreffende overheid - zou eveneens problematisch zijn. Het OM en het bedrijf dat zich schuldig makkte aan corruptie hebben immers geen van beide de expertise of de legitimiteit om dergelijke projecten in het buitenland uit te voeren. De internationale non-gouvernementele organisatie (ngo) Transparency International heeft het standpunt ingenomen dat het betreffende bedrijf in ieder geval geen enkele rol mag spelen bij de besteding van het compensatiegeld. ${ }^{101}$

Voor de verdere toekomst worden er door ngo's, wetenschappelijke instituten en $\mathrm{VN}$-organisaties al voorstellen gedaan over de wijze waarop met het compenseren van slachtoffers van corruptie om moet worden gegaan. Er wordt gepleit voor een mensenrechtenbenadering, waarbij geleerd kan worden van de verdragscomités van mensenrechtenverdragen over de wijze waarop grote groepen slachtoffers gecompenseerd kunnen worden. ${ }^{102}$ Er zijn zelfs verdergaande voorstellen tot het instellen van een nieuw VN-klachtenmechanisme voor corruptieslachtoffers, vergelijkbaar met de klachtenprocedures van mensenrechtenverdragen, en het instellen van een trustfonds voor slachtoffers, zoals het Internationaal Strafhof ook heeft. ${ }^{103}$

Voorlopig lijkt het voor Nederland het meest voor de hand te liggen dat er een constructie komt waarbij internationale of lokale ngo's een rol krijgen in het goed besteden van transactiegelden, nadat een schadevergoe-

99. Zie over de compensatie aan Tanzania in de BAE zaak C. Nicholls, et al. Corruption and misuse of public office, Oxford: Oxford University Press, 2011, p. 260 e.v.

100. In de zaak Odebrecht, in Zwitserland buitengerechtelijk afgedaan, betaalde het betreffende bedrijf rechtstreeks een compensatie aan enkele staten waaronder Guatemala. Zie bijvoorbeeld https:// www.reuters.com/article/us-guatemala-corruption/guatemala-saysodebrecht-agrees-to-pay-17-9-million-over-bribes-idUSKBN1FE09N.

101. Transparency International UK, Deterring and Punishing Corporate Bribery, May 2012, paragraaf 401.

102. Zie bijvoorbeeld Raoul Wallenberg Institute, Anti-Corruption and Human Rights: How to Become Mutually Reinforcing, 2018.

103. Statement By SERAP Nigeria to the UNCAC Implementation Review Group briefing for NGOs, Vienna, 30 May 2013. 
ding is vastgesteld als transactievoorwaarde. Het verdient aanbeveling dat er in Nederland richtlijnen komen voor transacties ter zake van buitenlandse corruptie, waarin een dergelijke constructie wordt uitgewerkt.

\section{Conclusie}

De Amerikaanse invloed op de Nederlandse handhavingspraktijk ten aanzien van buitenlandse corruptie is onmiskenbaar. Enerzijds kan de vraag worden opgeworpen waarom handhavers van Nederlandse strafwetten uitvoering zouden geven aan beleid dat Amerikaanse belangen ten goede komt. Anderzijds kan betoogd worden dat er voorafgaand aan deze amerikanisering in Nederland in het geheel geen sprake was van handhaving en dat straffeloosheid voor multinationale bedrijven geen enkele samenleving dient, de Nederlandse evenmin. In sommige opzichten kan zelfs een verdergaande amerikanisering worden bepleit, met name waar het gaat om de introductie van concrete richtlijnen waarin de factoren die bepalen wanneer een rechtspersoon in aanmerking komt voor een transactie - en de overwegingen die de hoogte van het transactiebedrag bepalen - zijn vastgelegd. Wij zien een vergelijkbare tegenstelling in het debat over buitengerechtelijke afdoening. Het is niet onterecht dat er discussie is over de rechtvaardigheid van transacties met grote multinationale bedrijven. Tegelijkertijd leek het zonder buitengerechtelijke afdoening vrijwel onmogelijk om strafrechtelijk op te treden tegen dergelijke bedrijven. Dit soort processen vergen simpelweg enorm veel kostbare capaciteit, terwijl er altijd proces- en executierisico's aan verbonden zijn. Hoewel wij menen dat er zeker aanleiding bestaat om maatregelen te treffen die tegemoetkomen aan de bezwaren die zijn geuit tegen de huidige transactiepraktijk in corruptiezaken, betwijfelen wij (mede gezien de ervaringen in de VS) of een rechterlijke toetsing van hoge transacties naar Amerikaans model hier de meest aangewezen oplossing is. Wat de door ons geschetste ontwikkelingen onzes inziens in elk geval laten zien, is dat de Nederlandse strafrechthandhaving steeds meer globaliseert. Niet alleen Europees strafrecht en internationale verdragen werken door in de Nederlandse handhaving, maar ook internationale en buitenlandse economische belangen. Wij bespraken in deze bijdrage niet alleen Amerikaanse belangen, maar ook die van multinationale ondernemingen en buitenlandse slachtoffers. Hoe er met al deze belangen omgegaan moet worden, verdient wat ons betreft nog veel meer discussie. Maar het is niet langer mogelijk om ze te negeren. 